\title{
Risk related to abuse of drugs in pregnant women
}

\author{
Risco relacionado ao consumo de drogas de abuso em gestantes
}

Rubia Mariana de Souza Santos ${ }^{1}$, Aroldo Gavioli ${ }^{1}$

Objective: to evaluate the riskrelated to druguse among pregnant women. Methods: this is a cross-sectional study, conducted with 209 pregnant women who answered the questionnaire for sociodemographic characterization and the Alcohol, Smoking, and Substance Involvement Screening Test. Descriptive and multivariate statistics were used. Results: there were $18.1 \%$ of the pregnant women with a moderate and high-risk level related to tobacco consumption, $27.2 \%$ with alcohol and $1.9 \%$ with marijuana. Levels of risk were statistically associated with less than eight years of non-white, Catholic education, living with a family of drug users, with a lower income than the sample mean, without children, living in a non-family household and aged between 14 and 24 years old. Conclusion: risk levels related to tobacco, alcohol, and marijuana consumption were high, being presented in vulnerable groups that should be the target of public policies for health promotion and prevention of drug use among pregnant women.

Descriptors: Pregnant Women; Street Drugs; Smoking; Alcoholism; Women's Health.

Objetivo: avaliar o risco relacionado ao consumo de drogas entre gestantes. Métodos: estudo transversal realizado com 209 gestantes que responderam ao questionário para caracterização sociodemográfica e ao instrumento Alcohol, Smoking and Substance Involvement Screening Test. Utilizaram-se estatísticas descritiva e multivariada. Resultados: dentre as gestantes, $18,1 \%$ apresentaram nível de risco moderado e elevado relacionado ao consumo de tabaco, 27,2\% de álcool e 1,9\% de maconha. Os níveis de risco foram estatisticamente associados com escolaridade inferior a oito anos, não brancas, católicas, que conviviam com familiar usuário de drogas, com renda abaixo da média amostral, sem filhos, vivendo em moradia não própria e com idade entre 14 e 24 anos. Conclusão: níveis de risco relacionados ao consumo de tabaco, álcool e maconha foram elevados, sendo apresentados em grupos vulneráveis que devem ser alvo de políticas públicas de promoção da saúde e prevenção do consumo de drogas entre gestantes.

Descritores: Gestantes; Drogas Ilícitas; Hábito de Fumar; Alcoolismo; Saúde da Mulher.

${ }^{1}$ Centro Universitário Uningá, Maringá, PR, Brazil. 


\section{Introduction}

The use of alcohol and other drugs is a major public health problem. In pregnant women, this problem is even more serious because it leads to irreversible impairment of the integrity of the mother and the fetus ${ }^{(1-2)}$. It is estimated that approximately $20.0 \%$ of women regularly use some drug (such as alcoholic beverages, tobacco cigarettes or joint).

Abuse of substances harmful to health in the pregnancy-puerperal period may be associated with restricted fetal growth, abortion, preterm birth, cognitive impairments in the concept, among others. Pregnant women who habitually consume such substances should be treated as at risk ${ }^{(3)}$. Alcohol and tobacco are the most commonly used drugs among drugs that are lawful or legally traded and represent one of the main causes of mortality and disability in developed countries. It is known that the consumption of alcohol and tobacco has harmful effects on the fetus, but it is not yet known for the minimum dosage responsible for the problems arising from its use during pregnancy. However, it is recommended that pregnant women avoid their consumption during this period ${ }^{(4)}$.

Marijuana is probably more used in gestation among the illicit drugs, followed by cocaine and its alkalized product, crack. There is little evidence of the deleterious effects of marijuana on the fetus and children born to female users, which does not diminish its growing importance. Cocaine is responsible for causing changes in the body of both the woman and the fetus, which can be perpetuated throughout childhood to adulthood. When present in the pregnant woman's blood, it can cross the placental membrane, passing through the blood vessels of the villus and the umbilical cord to the fetus ${ }^{(5-6)}$.

It is evident that, in general, women reduce the use of drugs of abuse during pregnancy, and that health professionals play an important role in reinforcing and supporting this behavior. However, some authors emphasize that even with all available information on the risks of abuse of drugs during pregnancy, it re- mains a difficult message to communicate in the context of addiction, which for many women, it is a chronic condition, sometimes having years of duration and occurring in an environment where other significant entities continue to use drugs of abuse, particularly tobacco $^{(6)}$.

Considering these and the fact that the access to information concerning the use of drugs of abuse for many women can be hampered by the stigma that the subject raises and by the illegality that is tangent to the subject, this study aimed to evaluate the risk related to abuse of drugs among pregnant women.

\section{Methods}

This is a cross-sectional study carried out with pregnant women at the Maternal and Child Health Clinic in a municipality located in the northwest of the State of Paraná, with a population estimated at 89,388 thousand inhabitants in $2014^{(7)}$.

The sample was calculated from a total of 380 women enrolled in the Monitoring System of the Prenatal and Birth Humanization Program, based on a maximum percentage of drug use of around $20.0 \%$, with a sampling error of $5.0 \%$ and confidence level of $95.0 \%$, resulting in a sample of 150 pregnant women. However, there was a low number of pregnant women who used drugs of abuse, opting for all prenatal care in the months of May and June 2015. A total of 213 pregnant women were enrolled, who were included in the inclusion criteria. Four pregnant women refused to participate in the study, which effectively resulted in a sample of 209 pregnant women.

The dependent variable analyzed was the risk related to the consumption of tobacco, alcohol, marijuana and cocaine during the gestational period, and the independent variables analyzed were age, marital status, number of children, living conditions, years of study, family income, skin color/race, religion, and drug use by family members.

A structured questionnaire was used for sociodemographic characterization and the instrument $\mathrm{Al}-$ 
cohol, Smoking, and Substance Involvement Screening Test (ASSIST) ${ }^{(8)}$.

ASSIST has been translated and validated in Brazil, and it is a screening questionnaire developed to detect the use of risk/harm and dependence on alcohol, tobacco, marijuana, cocaine, amphetamines, solvents, hypnotic-sedatives, hallucinogens, opiates and other substances. It consists of eight questions that address frequency of use in life and the last three months, problems related to use, concern about the use by people close to the user, loss of performance of expected tasks, unsuccessful attempts to cease or reduce the use, feeling of compulsion and use by injection $^{(8-9)}$.

Each answer corresponds to a score, and the total sum can range from zero to 39 . The score range from zero to 3 is considered as indicative of occasional use (low-risk level), from 4 to 26 as indicative of abuse (moderate risk level) and, when higher than 26, as suggestive of dependence (high-risk level). For alcohol, the range from 0 to 10 is considered as indicative of low risk, from 11 to 26 as indicative of moderate risk and when higher than 26 suggestive of dependence (high-risk level) ${ }^{(8-9)}$.

The collected data were compiled in a database using the IBM SPSS software and received statistical treatment by descriptive statistics, with the use of relative and absolute frequency, as well as dispersion measures, such as mean and standard deviation.

The data were dichotomized from the means, and multinomial logistic regression analysis was performed, using the odds ratio as a measure of association between the level of risk related to drug abuse and sociodemographic variables. Significant associations at the $95.0 \%$ confidence level were variables with an odds ratio greater than 1 . Due to the low number of pregnant women with a high risk of marijuana and cocaine use, regression analyses were not possible for these drugs of abuse.

The study complied with the formal requirements contained in the national and international regulatory standards for research involving human beings.

\section{Results}

Alcohol and tobacco were the drugs of abuse that presented a higher prevalence of use in life, that is, experimental use. Among the pregnant women, 86.1\% had tried alcohol, 35.4\% tobacco; 5.7\% marijuana and $1.4 \%$ cocaine. The mean age was 24.1 years old, ranging from 14 to 40 years old, with the majority in the age group of 14 to 20 years old. More than half were married or in stable union; $45.5 \%$ had the first pregnancy, $48.8 \%$ had a son, and $5.7 \%$ had 2 children or more; $46.9 \%$ lived in their house, and $53.1 \%$ lived in a rented house or assigned by a third party (living with relatives, for example); they had more than 8 years of study; they were white race/skin color; Catholic religion, and had brother/other/more than one relative who used alcohol, cigarettes and other drugs (Table 1).

Table 1 - Distribution of the sociodemographic variables frequency of the 209 pregnant women

\begin{tabular}{lc}
\hline Variables & $\mathbf{n}(\%)$ \\
\hline Age (years old) & $66(31.6)$ \\
$14-20$ & $59(28.2)$ \\
$21-25$ & $54(25.8)$ \\
$26-30$ & $21(10.0)$ \\
$31-35$ & $9(4.3)$ \\
$36-40$ & \\
Marital status & $16(7.7)$ \\
Single & $188(90.0)$ \\
Married/stable union & $5(2.4)$ \\
Separated & \\
Education (years) & $73(34.9)$ \\
Up to 8 & $136(65.1)$ \\
$>8$ & \\
Race/skin color & $148(70.8)$ \\
White & $57(27.3)$ \\
Brown & $4(1.9)$ \\
Black & \\
Religion & $109(52.2)$ \\
Catholic & $84(40.2)$ \\
Evangelical & $16(7.7)$ \\
Without religion & \\
Family member being a drug user & $150(71.8)$ \\
Brother/other/more than one & $33(15.8)$ \\
Father/mother & $26(12.4)$ \\
No &
\end{tabular}


Table 2 shows that most of the pregnant women were at low risk related to the use of drugs of abuse, $81.8 \%$ of tobacco consumption and $72.7 \%$ for alcohol. Regarding the risk range for health disorders related to consumption, that is, the risks classified as moderate and high, $18.1 \%$ of pregnant women were identified for tobacco consumption and $27.2 \%$ for alcohol. Regarding the use of illicit drugs, pregnant women were in the low-risk range for consumption, and only marijuana registered $1.9 \%$ of pregnant women at moderate risk. There were no pregnant women at risk related to cocaine use.

Table 2 - Distribution of pregnant women according to the classification of the level of risk related to the consumption of drugs of abuse

\begin{tabular}{lccc}
\hline \multirow{2}{*}{ Drugs } & \multicolumn{3}{c}{ Related risk level } \\
\cline { 2 - 4 } & Low n (\%) & Moderate n (\%) & High n (\%) \\
\hline Tobacco & $171(81.8)$ & $17(8.1)$ & $21(10)$ \\
alcohol & $152(72.7)$ & $54(25.8)$ & $3(1.4)$ \\
Marijuana & $205(98.1)$ & $4(1.9)$ & - \\
Cocaine & $209(100.0)$ & - & - \\
\hline
\end{tabular}

When analyzing the moderate risk related to the consumption of tobacco products, there were significant associations with the increase of the risk, with a level of education of fewer than eight years, non-white color race, family income below average, age between 14 and 24 years old and not having their house. Regarding the high level of risk, a significant association was observed at the level of $95.0 \%$ for the following variables: education less than eight years, non-white race, Catholic religion, living with a family member of a drug user, income and the number of pregnant women without children born (Table 3).
Table 3 - Effect of sociodemographic variables on the risk related to the consumption of tobacco derivatives and alcoholic beverages in 209 pregnant women

\begin{tabular}{|c|c|c|c|c|}
\hline \multirow{3}{*}{ Variable } & \multicolumn{3}{|c|}{ Tobacco derivates } & $\begin{array}{c}\text { Alcohol } \\
\text { beverages }\end{array}$ \\
\hline & Moderate & \multicolumn{2}{|c|}{ High } & Moderate \\
\hline & OR CI95\% & OR & CI95\% & OR CI95\% \\
\hline
\end{tabular}

Education (years)

$\begin{array}{lllllll}\text { Less than } 8 & 1.7 & 0.5-5.4 & 2.1 & 0.7-6.6 & 1.7 & 0.7-3.7\end{array}$

Race/skin color

No white

$1.4 \quad 0.4-4.2 \quad 3.3 \quad 1.2-9.1 \quad 1.4 \quad 0.6-3.0$

Religion

Catholic/no evangelical $\quad 1.4 \quad 0.3-6.0 \quad 3.0 \quad 0.9-9.4 \quad 1.4 \quad 0.6-3.0$

Family user

Presence

$\begin{array}{llllll}* & * & 1.0 & 0.2-6.1 & 2.7 & 0.9-9.0\end{array}$

Family income

Below average

$\begin{array}{llllll} & 0.9-6.0 & 2.5 & 0.8-8.1 & * & *\end{array}$

Age (years old)

14 to 24

$1.1 \quad 0.3-4.0$

House condition

Not own

$2.1 \quad 0.7-6.4$

Children

Withou children

$1.2 \quad 0.2-5.5$

*Not significant association in the confidence level of 95\%, OR<1. OR: odds ratio; CI95\%: confidence interval of $95.0 \%$

As for the moderate risk of alcoholic beverages, there was a significant association between 95.0\% and $80 \%$ in the variables of education less than 8 years, non-white race/skin color, Catholic religion and social interaction with drug users. At the high-risk level related to the consumption of alcoholic beverages, it was not possible to establish statistically significant associations. 


\section{Discussion}

The limits of the results of this study are related to the use of data reported in a situation that is perhaps not optimal, that is, during health service, which may result in the pregnant woman being insecure in providing information, due to the tangency of the illegality that the subject, leading to undersized data. On the other hand, there were advantages, since the nursing professionals develop bonds with the pregnant women, which facilitates such an approach. Another advantage is the use of standardized instruments, as it helps the professional in determining the limits, from which the consumption of drugs of abuse can be considered harmful.

In the screened sample, a high experimental use of drugs was observed, and this fact can demonstrate an important relation with the prevalence of habitual use and constitute a sustainable and long-lasting use. However, it is known that the evolutionary course followed by drug experiments is unknown, indicating that active prevention of the onset of consumption may be the only effective means of prevention ${ }^{(10)}$.

In a research conducted in Brazil, $18.2 \%$ of the pregnant women were users of drugs $(6.1 \%$ of alcohol users, $9.1 \%$ of tobacco, $0.5 \%$ of marijuana, $0.5 \%$ of crack $)^{(11)}$. In another study, a prevalence of $7.7 \%$ of pregnant women using tobacco was observed ${ }^{(12)}$. ASSIST showed that the most prevalent substance in use was tobacco (18.4\%), followed by alcohol (11.8\%) and marijuana, the most common illicit substance and used by $4.5 \%$ of pregnant women. The study also found that women, when pregnant, tended to decrease the use of substances of abuse, presenting rates significantly lower than before pregnancy ${ }^{(6)}$.

The II National Survey on Alcohol and Drugs, which compared alcohol use in two surveys in 2006 and 2012 , found a $20.0 \%$ increase in the rate of frequent drinkers, with the highest increase among women: they were $29.0 \%$ in 2006 , and they were $39.0 \%$ in
2012. This increase was seen for the standard drinking in "binge drinking," which in 2006 was $36.0 \%$ and in 2012 was $49.0 \%$. The study concluded that women are the most at-risk population, with higher rates of increase and more harmful drinking ${ }^{(13)}$.

Increasing consumption among women has already been the subject of other studies and may be associated with an increase in women's independence, greater participation of women in the labor market and the consequent increase in their income. The condition of moral and financial independence tends to induce the development of previously prevalent habits among men, such as frequenting bars with friends for the consumption of alcoholic beverages ${ }^{(14)}$. Such consumption can be sustained throughout gestation, becoming a health problem for the mother and the child.

The South Region of Brazil presented the highest level of smoking in a national survey in 2012, with $20.2 \%$ of smokers in the general population. In women, this study revealed that $13.0 \%$ are smokers ${ }^{(15)}$. This is very worrying because, when using an instrument such as ASSIST, which is sensitive to the level of risk related to consumption, it was observed that, in the sample, pregnant women presented a prevalence of use higher than this baseline study national.

Gestation is an ideal time to promote smoking cessation, and the nurse should be alert. Many women neglect or report minor consumption of the substance, predicting possible reprimand and disapproval by the health care provider. In this peculiar period, the use of drug-related risk screening instruments, such as the one used in this study, proved to be effective, easy to apply and, above all, capable of revealing the level of consumption that puts the mother and the child at risk $^{(6)}$

Harmful use of alcohol is one of the highest-impact risk factors for morbidity, mortality, and disability worldwide, and appears to be linked to 3.3 million deaths each year. Specifically, in disorders related to 
alcohol use, it is estimated that 5.6\% (Brazilian women: $3.0 \%$, men: $8.0 \%$ ) meet criteria for abuse or dependence. According to a report by the World Health Organization, $3.2 \%$ of Brazilian women present some alcohol-related disorder, and $1.8 \%$ have a diagnosis of dependence ${ }^{(16)}$.

Based on these findings and the harm from the use of drugs of abuse on the health of the fetus, it can be said that the use of alcohol during pregnancy is still significant, requiring preventive measures that help to reduce the incidence of new cases. At this moment, the nurse's role is important, since at no other stage of life does the woman use health services so frequently, which creates repeated opportunities for the detection of risk situations ${ }^{(6,11)}$.

Regarding the statistical association obtained through the multinomial logistic regression between sociodemographic factors and the risk levels related to the use of drugs of abuse, this study corroborates with others about drugs and gestation. Consistent and sustained consumption has been more frequently observed in young, non-white, Catholic women with low education and low income, coming from families in which there are drug users. Thus, pregnant women without resources and victims of political absence social groups that effectively target the pregnant drug user $^{(2,6,12) \text {. }}$

Among the actions that have been identified as effective are those of prevention, and on the public health side, it is necessary to prepare professionals, especially nurses, to confront the phenomenon of drugs during pregnancy and its importance to better address the problem, to promote the health of this patients, based on measures to prevent the use and abuse of illicit drugs ${ }^{(16)}$.

Both US and national studies show that the lower the educational level of the pregnant woman, the greater the possibility of drinking alcoholic beverages and the higher the rate of pregnant smokers ${ }^{(4)}$. The education level of the population has a debatable impact on the spread of the epidemic, and in the North and Northeast capitals, the prevalence of smokers is lower than in the South and Southeast.

In this study, it was not possible to establish sociodemographic associations with illicit drug use, but the sociodemographic profile found in the present sample and the profile of substance use may represent a risk factor for illicit drug use during pregnancy ${ }^{(4)}$. There is a shortage of studies on the use of marijuana during pregnancy. Research verified $7.5 \%$ of use in life and prevalence of recent use of $4.5 \%$. In these studies, younger women were more likely to use this substance $^{(6)}$.

Considering the findings of this study, the importance of intervention and prevention aimed at the cessation of smoking and alcohol consumption during the gestational period is perceived especially among pregnant women with low education, of non-white race/skin color. This is because the cessation of such habits before the gestational period is the guarantee of maximum protection to the fetus.

The risk screening tool used in this study was easy to apply and proved to be effective in detecting the prevalence of drug abuse and in determining the extent to which substance use is at risk. Given the consequences of substance use during pregnancy, the findings suggest that health professionals should reinforce and support the decision to stop using these substances during gestation.

The results of this study contribute to nursing since they revealed vulnerable groups among pregnant women, who should be the target of public policies for health promotion and prevention, also pointing to the importance of nurses taking a holistic look at pregnant women in the prenatal care. The use of a drug-related risk screening tool, ASSIST, has been shown to help in the investigation and identification of women who use drugs of abuse, providing a more qualified assistance. 


\section{Conclusion}

Tobacco and alcohol were the main drugs of legal abuse used by pregnant women. Marijuana was the main illicit drug consumed. Moderate and high-risk levels related to tobacco, alcohol, and marijuana consumption were significantly higher in this sample when compared to the results of other studies.

The risk (moderate and high) related to the consumption of alcohol and tobacco was significantly associated with pregnant women with less than 8 years of education, non-white, Catholic, living with a familiar drug user, with income below mean, who do not live in their house, aged between 14 and 24 years old. Significant statistical associations were not evidenced in this study, nor were pregnant women who consumed cocaine or even were included in the risk range for the use of this drug.

\section{Collaborations}

Santos RMS contributed to the design, preparation of the project, area data collection, analysis, data interpretation, final article writing and critical review of content. Gavioli A contributed to the preparation of the project, analysis, interpretation of the data and writing of the article and final approval of the version to be published.

\section{References}

1. Forray A. Substance use during pregnancy [version 1; referres: 2 approved] [Internet]. 2016 [cited 2016 Oct 13]. Available from: https://www. ncbi.nlm.nih.gov/pmc/articles/PMC4870985/ pdf/f1000research-5-8232.pdf

2. Santos MM, Porto PN, Oliveira JF, Pires CG, Araújo AJ. Associação entre características sociodemográficas e frequência de uso de álcool por gestantes. Rev Baiana Enferm. 2016; 30(2):1-9.
3. Lima LP, Santos AA, Povoas FT, Silva FC. O papel do enfermeiro durante a consulta pré-natal à gestante usuária de drogas. Rev Espaç Saúde. 2015; 16(3):39-46.

4. Rocha PC, Alves MT, Chagas DC, Silva AA, Batista RF, Silva RA. Prevalência e fatores associados ao uso de drogas ilícitas em gestantes da coorte BRISA. Cad Saúde Pública [Internet]. 2016 [citado 2016 out 13];; 32(1): e00192714. Disponível em: http://www.scielo.br/pdf/csp/v32n1/0102311X-csp-0102-311X00192714.pdf

5. Fabri RL, Siqueira LP, Fabri AC. Aspectos gerais, farmacológicos e toxicológicos da cocaína e seus efeitos na gestação. Rev Eletr Farm [Internet]. 2011 [citado 2016 out 13]; 8(2):75-87. Disponível em:https://revistas.ufg.br/REF/article/ view/14960/9303

6. Hotham E, Ali R, White J, Jeffrey R. Pregnancyrelated changes in tobacco, alcohol and cannabis use reported by antenatal patients at two public hospitals in South Australia. Aust and N Z J Obstet Gynaecol. 2008; 48(3):248-54.

7. Instituto Paranaense de Desenvolvimento Econômica e Social. Perfil do Município de Sarandi. Curitiba: IPARDES; 2014.

8. World Health Organization. Department of Mental Health and Substance Dependence. The Alcohol, Smoking and Substance Involvement Screening Test (ASSIST): Guideline for use in Primary Care. Draft Version 1.1 for Filed Testing [Internet]. 2010 [cited 2016 Oct. 20]. Available from: http://www. who.int/substance_abuse/activities/en/Draft_ The_ASSIST_Guidelines.pdf

9. Henrique IF, Micheli D, Lacerda RB, Lacerda LA, Formigoni ML. Validação da versão brasileira do teste de triagem do envolvimento com álcool, cigarro e outras substâncias (ASSIST). Rev Assoc Med Bras. 2004; 50(2):199-206.

10. Milanés ZC, Gómez-Bustamente E. Lifetime prevalence of drugs use in adolescents from Cartagena, Colombia. Invest Educ Enferm. 2012; 30(2):22430 .

11. Kassada DS, Marcon SS, Pagliarini MA, Rossi RM. Prevalence of drug abuse among pregnant women. Acta Paul Enferm. 2013; 26(5):467-71. 
12. Costa DO, Valença Neto PF, Ferreira LN, Coqueiro RS, Casotti CA. Consumo de álcool e tabaco por gestantes assistidas pela estratégia saúde da família. Rev Eletr Gestão Saúde [Internet]. 2014 [citado 2016 out. 20]; 5(3):934-48. Disponível em:http://gestaoesaude.unb.br/index.php/ gestaoesaude/article/viewFile/572/pdf

13. Instituto Nacional de Ciência e Tecnologia para Politicas Públicas de Álcool e Outras Drogas (BR). II Levantamento Nacional de álcool e droga: tendências entre 2006/2012 [Internet]. 2013 [citado 2016 out. 20]. Disponível em: http:// inpad.org.br/lenad/

14. Ferreira LN, Sales ZN, Casotti CA, Bispo Jr JP, Braga Jr AC. Perfil do consumo de bebidas alcoólicas e fatores associados em um município do Nordeste do Brasil. Cad Saúde Pública. 2011; 27(8):147386.
15. Carlini EA, Galduróz JC, Silva AA, Roto AR, Fonseca AM, Carlini CM, et al. II Levantamento Domiciliar Sobre o Uso de Drogas Psicotrópicas no Brasil: estudo envolvendo as 108 maiores cidades do país. São Paulo: Universidade Federal de São Paulo; 2006.

16. Mathiasen B. Políticas sobre drogas: ações abrangentes. [Internet]. 2010 [citado 2016 out. 20]. Disponível em: https://www.unodc.org/ lpo-brazil/pt/imprensa/artigos/2010/25-10politica-sobre-drogas-acoes-abrangentes.html 